strength came from, his wife Elaine and son Jordan. Charles always knew that the love, attention, and advice of Elaine and the joy of Jordie helped him remember what was important in life as he produced his legacy of scholarship, students, and friends. Memorial contributions from friends and colleagues may be made to the Charles H. Levine Memorial Fund, McLean School, 8224 Lochinver Lane, Potomac, MD 20854.

James $A$. Thurber and Bernard $H$. Ross The American University

\section{Gregory M. Luebbert}

Gregory M. Luebbert, assistant professor of political science at the University of California at Berkeley, died in a tragic boating accident in Idaho on May 24, 1988. Greg, aged 32, was an expert canoeist, known nationally for his daring and expertise.

Greg completed his B.A. at Lewis and Clark College in 1977. He received his Ph.D. in 1983 from Stanford University, after beginning his teaching career at Berkeley in 1982. During the academic year 1982-83, he was on leave from Berkeley and spent the year in the Netherlands under the auspices of the National Science Foundation.

A rising young star in the field of comparative politics, Greg completed several articles and a path-breaking book entitled Comparative Democracy: Policymaking and Governing Coalitions in Europe and Israel, in 1986. Shortly before his death, he had nearly completed another book, Social Foundations of Political Order in Inter-War Europe. Recipient of numerous awards and fellowships, during 1987-88, he was a Hoover National Fellow and holder of a Fulbright and German Marshall fellowship.

Fluent in over seven languages, Greg's work reflects deep historical and theoretical understanding of the politics of several countries. He exemplified the true comparative politics scholar, combining careful research skills with immense analytical sophistication.
As a teacher, Greg was highly admired and proved a great inspiration to dedicated graduate students. He guided them by example and by his insight and suggestions on how to tackle difficult problems. Greg always prodded his students to give the best of themselves.

For his many friends, colleagues, and students, Greg's untimely death at a time when his accomplishments were growing so rapidly, is a severe blow. The only solace is that those of us who knew him personally were fortunate to have been exposed to his brilliance and humor. His ideas and example will continue to inspire his many admirers.

A Gregory M. Luebbert Memorial Fellowship for graduate students in Greg's department has been established. Donations, made to the Regents of the University of California, can be mailed to the Department of Political Science, University of California, Berkeley, CA 94720 (c/o Professor Austin Ranney, Chairman).

Vinod K. Aggarwal
Giuseppe Di Palma
University of California, Berkeley

Harvey C. Mansfield, Sr.

Harvey C. Mansfield, Sr., died at the age of 83 at his home in New York City, April 27, 1988, after several months of illness. At his death he was Ruggles Professor of Public Law and Government Emeritus at Columbia University, and had enjoyed a notable and diverse career in political science.

Harvey was born in Cambridge, Massachusetts, March 3. 1905, and lived as a boy in Washington, DC. After his junior year in high school he attended Deep Springs College, a tiny junior college in California which combined ranch work and study. From there he went to Cornell where he obtained A.B. and A.M. degrees in 1927 and 1928, majoring in government and history. He went immediately to Columbia where he studied one year and ultimately received his Ph.D. in 1932. He studied under such luminaries of the day as Robert 